\title{
Effect of Repeated Movements on Motion Perception and Motor Learning of Dominant and Non-dominant Upper Extremity of Healthy Individuals
}

\section{Sağlıklı Gençlerde Üst Ekstremite Dominant ve Non-dominant Tarafta Tekrarlı Hareketin Hareket Algısı ve Motor Öğrenmeye Etkisi}

(i) Deniz KOCAMAZ1, id Songül ATASAVUN UYSAL2², id Elif DINLER¹, id Tuğba BADAT¹, id Begümhan TURHAN1,

(i) Yavuz YAKUT ${ }^{1}$

${ }^{1}$ Hasan Kalyoncu University Faculty of Medicine, Department of Physical Therapy and Rehabilitation, Gaziantep, Turkey

${ }^{2}$ Hacettepe University Faculty of Medicine, Department of Physical Therapy and Rehabilitation, Ankara, Turkey

\begin{abstract}
Objective: Hand dominancy can be observed as right, left, or the usage of bilateral hands. Majority of the Turkish population are right-hand dominant. This study aimed to examine and interpret the motion perception and motor learning of the dominant and non-dominant upper extremity.

Methods: A total of 146 right-hand dominant university students participated in this study. The mean age of participants was $23.0 \pm 1.99$, wherein 80 were female $(54.79 \%)$ and 66 were male (45.21\%). Hand preference was evaluated by the Edinburgh Hand Preference Questionnaire. Participants were positioned at the table edge with the hip, knee, and elbows at 90 degrees flexion. Measurements were made on a special platform. Participants were asked to place the glass at the center point, with a $25 \mathrm{~cm}$ distance from the rangefinder, and their eyes closed. Measurements were repeated 3 times on both dominant and non-dominant sides. The distance and deviation rate from the center point were recorded in $\mathrm{cm}$ with the laser rangefinder. Statistical Package for the Social Sciences 21.0 program was used in the analysis.

Results: According to the Edinburg Hand Preference Questionnaire, 42 of participants $(28.76 \%)$ were strong right dominant, 95 $(65.06 \%)$ were weak right dominant, and $9(6.18 \%)$ were weak left dominant. The mean of distance from the central point for three measurements during the activity of glass placing were $2.56 \pm 1.91$ $\mathrm{cm}$ on the dominant side and $2.57 \pm 1.86 \mathrm{~cm}$ on the non-dominant
\end{abstract}

\section{ÖZ}

Amaç: El dominansı; sağ dominant, sol dominant veya bilateral el kullanılması şeklinde görülmektedir. Sağ dominant bireylerin çoğunlukta olduğu toplumumuzda dominant ve non-dominant tarafta tekrarlı hareketlerin hareket algısı ve motor öğrenmeye etkisinin incelenmesi ve yorumlanabilmesi amacıyla bu çalışma planlanmıştır.

Yöntemler: Çalışmaya yaş ortalaması $23.0 \pm 1,99$ yıl olan, 80 'i kadın $(\% 54,79), 66$ sı erkek $(\% 45,21)$ olmak üzere 146 gönüllü sağ eli dominant olan üniversite öğrencisi katıldı. El tercihi Edinburg El Tercih Anketi ile değerlendirildi. Bireyler kalça, diz ve dirsekler $90^{\circ}$ fleksiyonda olacak şekilde masa kenarında pozisyonlandı. Ölçümler özel platform üzerinde yapıldı. Bireylerden, gözler kapalı iken, uzaklık ölçerden $25 \mathrm{~cm}$ mesafedeki merkez noktaya bardağı yerleştirmesi istendi. Ölçümler 3 kez dominant ve non-dominant tarafta tekrarlandı. Merkez noktaya uzaklık ve sapma miktarı lazerli uzaklık ölçer ile $\mathrm{cm}$ cinsinden kaydedildi

Bulgular: Edinburg El tercih anketine göre bireylerin 42' 1 (\%28,76) kuvvetli sağ dominant, 90’’ (\%65,06) zayıf sağ dominant, 9'u $(\% 6,18)$ zayıf sol dominanttı. Bardak yerleştirme aktivitesi sırasında merkez noktadan uzaklıkların üç ölçüm için ortalaması dominant tarafta $2,56 \pm 1,91 \mathrm{~cm}$, non-dominant taraf için ise $2,57 \pm 1,87 \mathrm{~cm}$ 'di. Dominant ve non-dominant el açısından merkez noktadan uzaklık ölçümleri açısından anlamlı fark bulunmadı (p>0,05). Ancak

Address for Correspondence: Deniz KOCAMAZ, Hasan Kalyoncu University Faculty of Medicine, Department of Physical Therapy and Rehabilitation, Gaziantep, Turkey E-mail: denizerdan@gmail.com ORCID ID: orcid.org/0000-0002-0611-7686

Cite this article as: Kocamaz D, Atasavun Uysal S, Dinler E, Badat T, Turhan B, Yakut Y. Effect of Repeated Movements on Motion Perception and Motor Learning of Dominant and Non-dominant Upper Extremity of Healthy Individuals. Bezmialem Science 2021;9(1):3-8. 
side. No significant difference was observed in terms of distance from the center point in dominant and non-dominant hand $(p>0.05)$. However, when results of the deviation from the center of three measurements were examined in the dominant side, according to the deviation distance, the first measurement was found closer to the center point than the second and third measurement results $(\mathrm{p}<0.05)$.

Conclusion: It is thought that the first measurement results are closer to the center with the effect of visual memory at the dominant and non-dominant sides, but in the second and third repetitions, it is thought that the deviation from the center is due to the short term memory, kinesthesia, and motor learning ability which could not be coded correctly.

Keywords: Dominant side, non-dominant side, motor learning, visual memory, right-hand dominance, left-hand dominance dominant tarafta ardı ardına yapılan üç ölçümün merkezden sapma mesafesi sonuçları incelendiğinde birinci ölçüme dair sapmanın, ikinci ve üçüncü ölçüm sonuçlarına göre merkez noktaya daha yakın olduğu tespit edildi $(\mathrm{p}<0,05)$.

Sonuç: Dominant ve non-dominant taraf ölçüm sonuçlarına göre görsel hafızanın etkisi ile ilk ölçüm sonuçlarının merkeze daha yakın olduğu, ikinci ve üçüncü tekrarda kısa süreli hafıza, kinestezi ve doğru kodlanamayan motor öğrenme becerisi nedeniyle merkez noktadan uzaklaşıldığı düşünülmektedir.

Anahtar Sözcükler: Dominant taraf, non-dominant taraf, hareket algısı, motor öğrenme, sağ el dominansı, sol el dominansı

\section{Introduction}

Motor control is a result of motor learning provided by the dominant hemisphere. During motor learning and motor control, the primary motor cortex provides individual or synergistic movements of the extremity muscles when the motor cortex is stimulated. The premotor cortex is responsible for motor movements learned for a general function and posture task for movements. Another important feature of the premotor cortex is that it has mirror neurons in its silent activation. These neurons observe the movement, and release the same movement. Similarly, it is important in mental imaging, activation in mirror neurons under the premotor cortex and parietal cortex, motor perception, motor learning, empathy, imitation, and learning new motor movements. The parietal cortex is also related to the feeling of discrimination. Brodmann areas, ranking between 3-2-1, are particularly related to somatosensory senses. Thalamic fibers are also origin from areas $3 \mathrm{a}$ and $3 \mathrm{~b}$. Areas 2 and $3 \mathrm{a}$ have an important role in proprioception and kinesthesia (1).

Cerebral lateralization is the capacity of a hemisphere (usually left) to provide more control of the contralateral side of the body compared to the other hemisphere. In this way, the contralateral side movements occur to be more accurate, rapid, and coordinated (2). The left hemisphere, which provides sensory and motor functions on the right side of the body, is the center of intellectual abilities. The right hemisphere, which controls the left side of the body, is responsible for the analysis of complex structures, holistic approach, determination of direction, and shapes of objects. Although both right and left sides of the body are used during different activities, one half of the brain dominates specialized and skill-related activities (3). It is essential to acquire skills with the use of dominant sides, to keep the gained skills in the short term memory, and to ensure its permanence. In this way, information is transferred to long-term memory, and motion perception develops (4).

Studies have shown that dominant hand use is associated with fine motor skills. In addition, studies have shown significant differences between dominant and non-dominant hand regarding asymmetry, number of hits, and completion time (5). Strength of hand grip and motion perception is associated with muscle strength in the upper extremity. Studies have shown that hand gripping force and load distribution have a significant effect on the hand function. The importance of thumb, ring finger, and palms in determining the motion perception and the grip in the dominant hand was emphasized $(6,7)$. In the literature, studies conducted with university students suggested that somatosensory stimuli changes brain activation and long-term memory skills (8).

Obviously, data on literature is needed which includes not only the use of dominant upper extremity in healthy individuals depending on parameters such as muscle and grip strength, age, height, body mass index, and gender but also vary from the reaction time to motion perception and distance determination in young adults according to auditory stimuli (6).

In light to this information, we can say that short-term memory is more effective in just experienced movements. Factors such as repeated movement and planning of motion may take a part in motor learning and control. The hypothesis of this study is that repeated movements are effective on motion perception and motor learning of the upper extremity.

\section{Method}

\section{Ethical Approval}

This study was carried out at Hasan Kalyoncu University, Physical Therapy and Rehabilitation Department of Health Science Faculty. Ethical approval was obtained from the Local Ethics Committee, for the study on March 21, 2017 with the decision number 2017-02. The study was carried out in accordance with principles defined in the Declaration of Helsinki. Participants were informed about the study, and the informed consent form was signed.

\section{Participants}

A total of 146 students aged between 18 and 30 years, who are right-handed writers participated in this study. Those who are older than 30 years old, left-handed writers and those who use 
bilateral hands during writing were excluded. Age and gender information of participants were recorded.

\section{Apparatus and Procedure}

In this study, participants were positioned at the table edge with the hip, knee, and elbows at 90-degree flexion. Measurements were made on a special platform. Figure 1 shows the experimental setup. The platform was designed to allow the upper extremity movement up to 180 degrees and to place two laser rangefinder. Both right and left forearms were resting on the table. In the study, a distance of $25 \mathrm{~cm}$ from each laser rangefinder was determined as the center point, and two matted glasses were placed. Participants were informed about the center point and the desired activity with their eyes open. Participants were asked to experience places on the platform, where the glasses are, while their eyes were opened. First, they were asked to keep the glass in its place, then to raise the glass once, and leave it to the same center point again. During evaluations, participants were asked to take the glass passed from different distances and put it on the center point. During the activity, glasses were passed from different arm angles. Measurements were repeated 3 times in the dominant and then the non-dominant side. The distance from the center point and the deviation rate were recorded in $\mathrm{cm}$ with the laser rangefinder. All evaluations were performed in a quiet hall with at least two physiotherapists who were among the authors of the study.

The hand preference of individuals was determined by the Edinburg Hand Preference Questionnaire, which was modified by Geschwind and Behan. Questions in this survey were related to simple daily functions. The hand preference of participants was asked while writing, painting, ball and stone throwing, scissoring, tooth brushing, holding a knife while slicing bread, holding a fork without a knife, rowing (bottom hand), hammer

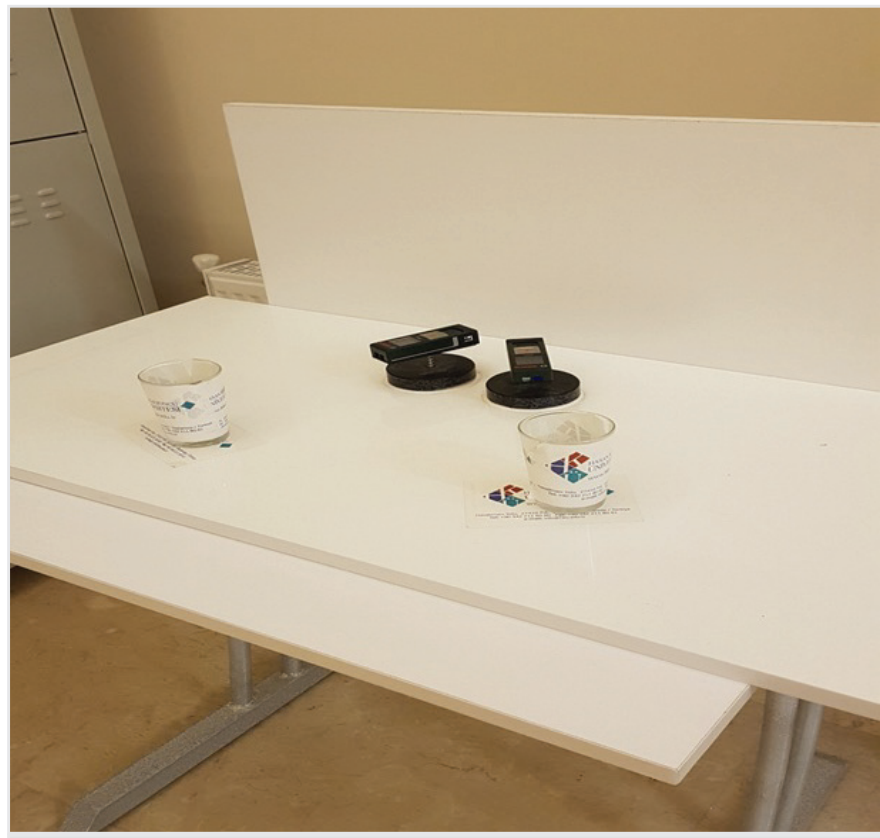

Figure 1. Evaluation platform holding, holding a match, and opening a lid. Answers ranged between "always right," "usually right," "with bilateral hands," "left," and "always left," and for answers respectively $+10,+5$, $0,-5$, and -10 points were given (9). The value from +100 to -100 was called the Geschwind score (GS). Negative scores refer to left-handedness whereas positive scores refer to righthandedness. In GS, the hand preference score ranges between -80 and -100 suggests strong left-dominant, between -20 and -70 suggests weak left-handedness, and between -15 and 15 refers to two-handedness. Score ranges from 20-75 suggests weak rightdominant and 80-100 refers to strong right-dominant (10).

\section{Statistical Analysis}

Statistical analysis was performed using Statistical Package for the Social Sciences 21.0 (SPSS Inc., Chicago, USA). The distance from the laser rangefinder was calculated as mean \pm standard deviation $(\mathrm{X} \pm \mathrm{SD})$. The deviation from the center point was calculated as the difference $\pm \mathrm{SD}(\mathrm{D} \pm \mathrm{SD})$ in dominant and non-dominant sides. The correspondence of variables to the normal distribution was examined by visual (histogram and probability graphs) and analytical methods (Shapiro-Wilks test). Paired Sample t-test was used to compare the difference between dominant and non-dominant sides. The margin of error was accepted as $\mathrm{p}<0.05$.

\section{Results}

In this study, we examined effects of repeated movements on the motion perception and motor learning of the dominant and non-dominant upper-extremity in healthy individuals.

\section{Characteristics of Participants}

A total of 146 right-hand dominant volunteers participated, wherein 80 were females $(54.79 \%)$ and 66 were males $(45.21 \%)$ with mean age of $23.0 \pm 1.99$. All participants were university students. According to the Edinburgh Hand Preference Questionnaire, 42 of participants $(28.76 \%)$ were strong righthanded, 95 (65.06\%) were weak right-handed, and 9 (6.18\%) were weak left-handed.

\section{Distance from the Laser Rangefinder and Deviation from the Center Point}

In the motion perception and motor learning of the dominant and non-dominant side evaluation, 3 repeated measurements were performed while their eyes were closed. No significant differences were noted in all measurements in terms of gender ( $\mathrm{p}>0.05)$.

The mean and standard deviation of the distance from the laser rangefinder and the deviation from the center point for three measurements during the activity of placing the glass are shown in Table 1 for the dominant and non-dominant sides. No significant differences we noted between the dominant and nondominant sides ( $\mathrm{p}>0.05)$ (Table 1$)$.

No differences were noted between the dominant and nondominant sides in terms of deviation differences from the center point with their eyes closed (Table 2, p>0.05). 
In non-dominant side, deviation from the center point was also similar. But in dominant side measurements, the deviation from the center point of the first evaluation was closer than the second and third evaluations. (Table $2, \mathrm{p}<0.05$ ). No difference was noted between the second and third evaluations of dominant hands (Table 2, p>0.05).

\section{Discussion}

In this study, repeated movements on motion perception and motor learning of the upper extremity dominant and nondominant side in healthy young individuals with right-hand dominancy was evaluated on a specially developed platform. It is determined that the distance from the laser rangefinder and deviation from the center point for three measurements during the activity of placing glass were similar at dominant and nondominant sides.

In literature it is determined that in studies which evaluate motion perception and learning, right-dominant individuals were preferred. When studies were examined in terms of average ages, it was seen that young individuals could better adapt to the study design, and these adaptations could be perceived more easily in terms of cognition $(11,12)$. In this study, right-dominant individuals were preferred in accordance with the literature. Our results did not differ between genders, thus gender comparisons were not made in our sample.
Hemispheric lateralization is mainly parallel to hand dominancy (13). Hand dominancy may change over time due to environmental factors such as educational and cultural influences, but the hemispheric dominance is constant $(14,15)$. Although results of the Edinburgh Hand Preference Questionnaire used for the determination of hand dominancy in our study were in parallel with the hemispheric dominance, the hemispheric dominance with this measurement method could not be determined precisely and accurately. In addition, in this questionnaire, the dominant hand preference is determined by hand use in daily life, the determination of hand preference as strong and weak suggests that hemisphere dominance may change. We attributed this to the fact that people may be affected by the environment in determining hand choices. Furthermore, other methods could be used to determine hemispheric dominancy. Results of this study were evaluated according to the literature with consideration of the hand dominancy. Only the right-hand dominant individuals were included in this study due to less frequent left-hand dominant individuals in Turkish population. We think that results of studies comparing the right and lefthand dominant individuals may contribute to the evaluation of motion perception and learning.

The coordination of the musculoskeletal system is ensured by the coordinated work of sensory and motor areas in the cortex. The left and right brain hemispheres are responsible for controlling the contralateral side of the body through commissural fibers.

Table 1. The distance from the laser rangefinder on dominant and non-dominant sides (mean \pm standard deviation) (cm)

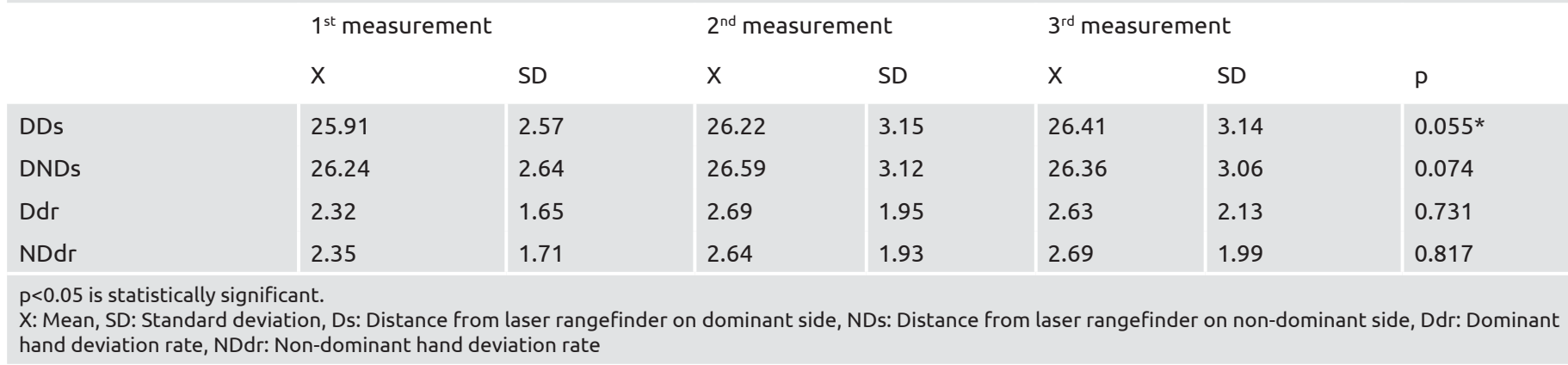

Table 2. Comparison of deviation differences between measurements on dominant and non-dominant sides (deviation \pm standard deviation) $(\mathrm{cm})$

\begin{tabular}{|c|c|c|c|c|}
\hline Evaluations & D & SD & $\mathrm{T}$ & $\mathrm{p}$ \\
\hline Ds 1-NDs 1 & 0.02 & 2.59 & -0.096 & 0.924 \\
\hline Ds 2-NDs 2 & 0.08 & 3.22 & -0.286 & 0.776 \\
\hline Ds 1-Ds 2 & 0.40 & 1.95 & 1.961 & $0.035 *$ \\
\hline Ds 1-Ds 3 & 0.49 & 2.35 & -2.175 & 0.020 * \\
\hline NDs 1-NDs 2 & 0.25 & 2.30 & 1.286 & 0.200 \\
\hline NDs 1-NDs 3 & 0.13 & 2.84 & -0.534 & 0.594 \\
\hline NDs 2-NDs 3 & 0.27 & 2.25 & -1.887 & 0.059 \\
\hline
\end{tabular}


Although different discriminators have been mentioned in the concept of cerebral dominancy, hand preference has been one of the most studied subjects by clinical and preclinical sciences as a symptom of motor dominancy. Ocklenburg and Gunturkun (14). investigated the relationship between hand preference and gender with the university students, their study stated that participants generally preferred their right hands in jobs that require skill, and it would be appropriate to evaluate the anatomically symmetrical brain hemispheres in terms of functionality. In this, we planned to evaluate repeated movements on motion perception and motor learning of healthy young individuals, and it was concluded that hand dominancy was not a distinguishing factor in terms of motion perception, motor learning, and functionality. Similar effects were observed with the non-dominant side with their eyes closed.

In literature, it is observed that special platforms with sensors are preferred in studies where motor control is examined. Mathew et al. (11) investigated handedness and motor control in their study. They stated that dominancy is not a predictive factor in the determination of motor control. We have used a special platform for measurements. It is determinate that the distance from the laser rangefinder and deviation from the center point for three measurements during activity of placing glass were similar at dominant and non-dominant sides. In group comparisons, a difference was only noted on the dominant side. The first measurement results for the dominant side were closer to the center point, the second measurements deviated from the center point, and the third measurement has less deviation from the center point than that of the second measurements. It is thought that the first measurement results are the effect of visual memory at the dominant and non-dominant side, but in the second and third repetitions, it is thought that the deviation from the center is due to the short term memory, kinesthesia, and motor learning ability which could not be coded correctly. Therefore, more detailed studies explaining the motion perception and motor learning explaining the comparative results of the right- and lefthand dominancy are necessary.

In light of this information, it is clear that hand dominancy is not a predictive factor for motor control and motor learning. We thought that these may be related to gender, education level, social, and cultural level as well as its use during daily life activities.

The declarative memory, which is the sub-group of longterm memory, is defined as the idea and schematization of the information which is conscious. Motions and skills occur unconsciously in the other subgroup of long-term and procedural memory. While learning a motor activity, the first thing to do is to formulate ideas, and the memory progresses from the declarative to the procedural (16). In the light of the information of the cortex and sub-cortex structures, it is the memorization of the coded motion with the repetition of the planned motor movement and with the relationship with basal ganglia and cerebellum. As a result of evaluations, the deviation in the first measurements of the dominant side was found to be similar, and the deviation from the center point in the second and third measurements was found to be higher. These findings can be explained by the relationship between motor learning, motor control, and memory. This situation can be interpreted as participants acted by focusing more on the activity, and by formulating ideas during the first evaluation and in the following evaluations, they acted under the influence of procedural memory.

\section{Study Limitations}

The limitation of the study includes the absence of auditory impulse for confusion during measurements. All measurements were performed in a silent room. Different age groups could be included in future studies, and differences between age groups could be examined.

\section{Conclusion}

In the study, which examined the motion perception and motor control of the dominant and non-dominant upper extremity in healthy young individuals, it was stated that hand dominancy not a main determinant. Repeated movements, visual information, short-term memory, and correct coding could affect the motor ability.

This study also updates the old literature on this subject. A need for further studies in this field is seen by including the rightand left-hand dominant individuals, and evaluating visual and auditory interference during movements.

\section{Ethics}

Ethics Committee Approval: This study was carried out at Hasan Kalyoncu University, Physical Therapy and Rehabilitation Department of Health Science Faculty.

Informed Consent: Participants were informed about the study, and the informed consent form was signed.

Peer-review: Externally peer reviewed.

\section{Authorship Contributions}

Concept: D.K., Y.Y., Design: D.K., Y.Y., Data Collection or Processing: D.K., E.D., T.B., Analysis or Interpretation: S.A.U., B.T., Y.Y., Literature Search: D.K., S.A.U., E.D., T.B., B.T., Y.Y., Writing: D.K., S.A.U., E.D., T.B., B.T.

Conflict of Interest: No conflict of interest was declared by the authors.

Financial Disclosure: The authors declared that this study received no financial support.

\section{References}

1. Vuoksimaa E, Koskenvuo M, Rose RJ, Kaprio J. Origins of handedness: A nationwidestudy of 30161 adults. Neuropsychologia 2009;47:1294301.

2. Teixeira L, Silva MV, Carvalho M. Reduction of lateral asymmetries in dribbling: The role of bilateral practice. Laterality 2003;8:53-65. 
3. Yıldırım S, Dane Ş. Serebral lateralizasyon ve el tercihi. EAJM 2007;39:45-8

4. Yonelinas AP. The hippocampus supports high-resolution binding in the service of perception, working memory and long-term memory. Behav Brain Res 2013;254:34-44.

5. Sebastjan A, Skrzek A, Ignasiak Z, Sławińska T. Age-Related changes in hand dominance and functional asymmetry in older adults. Plos One 2017;e0177845.

6. Cai A, Pingel I, Lorz D, Beier JP, Horch RE, Arkudas A. Force distribution of a cylindrical grip differs between dominant and nondominant hand in healthy subjects. Arch Orthop Trauma Surg 2018;138:1323-31.

7. Narin S, Demirbüken İ, Özyürek S, Eraslan U. Dominant el kavrama ve parmak kavrama kuvvetinin önkol antropometrik ölçümlerle ilişkisi. DEÜ Tıp Fakültesi Dergisi 2009;23:81-5.

8. Göktepe G. Effect of bilateral somatosensory stimulus on oscillatory brain activity and long term memory. Orta Doğu Teknik Üniversitesi 2017.

9. Oldfield RC. The assessment and analysis of handedness: The Edinburgh Iventory. Neuropsychologia 1971;9:97-103.
10. Tan U. The distribution of the Geschwind scores to familial lefthandedness. Int J Neurosci 1988;42:85-105.

11. Mathew J, Sarlegna FR, Bernier PM, Danion FR. Handedness matters for motor control but not for prediction. eNeuro 2019;6:ENEURO.0136-19.2019.

12. Di Tore PA, Schiavo R, D'Isanto, T. Physical education, motor control and motor learning: Theoretical paradigms and teaching practices from kindergarten to high school. Journal of Physical Education and Sport 2016;16:1293-7.

13. Akça F, Çekin R, Ziyagil MA. Genç erkeklerde el dominansının hedefli yüksek atış performansına etkisi. CBÜ Bed Eğt Spor Bil Dergisi 2015;10:1-8.

14. Ocklenburg S, Gunturkun O. Hemispheric asymmetries: the comparative view. Front Psychol 2012;3:5.

15. Aliosmanoğlu B, Köçkar Ç. Üniversite öğrencilerinde el tercihinin ve dominant gözün bazı hastalıklar ile ilişkisi. Eur J Basic Med Sci 2014; $4: 53-7$.

16. Jones G, Macken B. Long-term associative learning predicts verbal short-term memory performance. Memory \& Cognition 2018;46:216-29. 